NBER WORKING PAPER SERIES

\title{
CORPORATE GOVERNANCE AND \\ THE PLIGHT OF MINORITY SHAREHOLDERS \\ IN THE UNITED STATES BEFORE THE GREAT DEPRESSION
}

\author{
Naomi R. Lamoreaux \\ Jean-Laurent Rosenthal \\ Working Paper 10900 \\ http://www.nber.org/papers/w10900 \\ NATIONAL BUREAU OF ECONOMIC RESEARCH
1050 Massachusetts Avenue
Cambridge, MA 02138
November 2004
}

The authors have benefited from the advice of Robert Allen, Steven A. Bank, Ruth Bloch, Hongbin Cai, Judith Chevalier, Paul David, Lance Davis, Harold Demsetz, Stanley Engerman, Edward Glaeser, Claudia Goldin, Peter Gourevitch, Timothy Guinnane, Henry Hansmann, Ron Harris, Susan Helper, Philip Hoffman, Hugo Hopenhayn, Gonzalo Islas, Gregory Mark, Chris McKenna, Joel Mokyr, William Novak, Gilles Postel-Vinay, James Rebitzer, Arthur Rolston, Roberta Romano, Kenneth Sokoloff, John Wallis, and Matt Wiswall, as well as from the comments of participants in seminars at the Yale Law School, Oxford University, Case Western Reserve University, UCLA, at a meeting of the Greater Chicago Economic History Group, at the Conference on the Political Economy of Financial Markets held at Princeton University, and the NBER Conference on Corruption and Reform. We also grateful for the assistance of Eric Torres in searching newspapers and other periodical sources. The views expressed herein are those of the author(s) and not necessarily those of the National Bureau of Economic Research.

(C) 2004 by Naomi R. Lamoreaux and Jean-Laurent Rosenthal. All rights reserved. Short sections of text, not to exceed two paragraphs, may be quoted without explicit permission provided that full credit, including () notice, is given to the source. 
Corporate Governance and the Plight of Minority Shareholders in the United States Before the Great Depression

Naomi R. Lamoreaux and Jean-Laurent Rosenthal

NBER Working Paper No. 10900

November 2004

JEL No. N4, K2

\begin{abstract}
Legal records indicate that conflicts of interest - that is, situations in which officers and directors were in a position to benefit themselves at the expense of minority shareholders - were endemic to corporations in the late-nineteenth and early-twentieth century U.S. Yet investors nonetheless continued to buy stock in the ever increasing numbers of corporations that business people formed during this period. We attempt to understand this puzzling situation by examining the evolution of the legal rules governing both corporations and the main organizational alternative, partnerships. Because partnerships existed only at the will of their members, disputes among partners had the potential to lead to an untimely (and costly) dissolution of the enterprise. We find that the courts quite consciously differentiated the corporate form from the partnership so as to prevent disputes from having similarly disruptive effects on corporations. The cost of this differentiation, however, was to give controlling shareholders the power to extract more than their fair share of their enterprise'"s profits. The courts put limits on this behavior by defining the boundary at which private benefits of control became fraud, but the case law suggests that these constraints became weaker over our period. We model the basic differences between corporations and partnerships and show that, if one takes the magnitude of private benefits of control as given by the legal system, the choice of whether or not to form a firm, and whether to organize it as a partnership or a corporation, was a function of the expected profitability of the enterprise and the probability that a partnership would suffer untimely dissolution. We argue that the large number of corporations formed during the late nineteenth and early twentieth centuries were made possible by an abundance of high-profit opportunities. But the large number of partnerships that also continued to be organized suggests that the costs of corporate form were significant.
\end{abstract}

Naomi R. Lamoreaux

Department of Economics

UCLA

405 Hilgard Avenue

Los Angeles, CA 90095-1477

and NBER

lamoreaux@econ.ucla.edu
Jean-Laurent Rosenthal

Department of Economics

UCLA

Los Angeles, CA 90095-1477

rosenthal@econ.ucla.edu 


\section{Corporate Governance and the Plight of Minority Shareholders in the United States before the Great Depression}

The promoters ... had their reasons for celebration. ... [T]hey had set up the Crédit Mobilier, into whose chest the gains from contracts for the whole Union Pacific building had flowed. . . . The proceeds from government bonds, security sales, and sales of lands and town sites had all been swallowed up in the mounting costs of building or in other ways. For this work the directors of the Union Pacific had ingeniously contracted with themselves at prices which rose from $\$ 80,000$ to $\$ 90,000$ and $\$ 96,000$ a mile, twice the maximum estimates of engineers. ... Hence the jubilation of the Union Pacific ring. For what profits could they have awaited, if they had confined themselves purely to trafficking in freight or passengers through the empty prairies?

- Matthew Josephson $(1934,92)$

\section{Introduction}

The Crédit Mobilier manipulation was a spectacular scandal. Directors of the Union Pacific Railroad had organized their own construction company and had awarded themselves the contract to build the transcontinental line. Although historians have long debated whether or not this arrangement yielded participants an exorbitant rate of return, ${ }^{1}$ there is no doubt contemporaries thought it did. What made headlines, however, was less this siphoning off of profits than the involvement of the federal government, which had granted the Union Pacific

\footnotetext{
${ }^{1}$ Compare, for example, the accounts in Josephson 1934 and Bain 1999 with those of Kirkland 1961 and Summers 1993.
} 
extensive tracts of public lands and also loans to finance construction. Newspaper reports charged that the "railroad ring" had bought political influence by handing out shares in Crédit Mobilier to influential Congressman, presumably with the aim of securing additional federal largess, not to mention forestalling inconvenient scrutiny (Josephson 1934; Bain 1999). ${ }^{2}$

The hoopla that surrounded these revelations of bribery has obscured for modern observers the extent to which conflicts of interest, like those at the heart of the Crédit Mobilier scandal, were endemic to corporations at the time. Although cases rarely made headlines unless they involved companies, such as major railroad or telegraph lines, that were important to the public welfare ${ }^{3}$ the legal record from the late nineteenth and early twentieth centuries suggests that directors of corporations large and small frequently negotiated contracts with other companies in which they had a financial interest, ${ }^{4}$ elected themselves to corporate offices at lucrative salaries that they themselves set, ${ }^{5}$ arranged mergers that earned themselves impressive capital gains while leaving other shareholders in the lurch, ${ }^{6}$ and engaged in a wide variety of

\footnotetext{
${ }^{2}$ Intriguingly, details of the Crédit Mobilier manipulation had been reported in the press since at least 1869 , but attracted little attention until the New York Sun, which opposed the reelection of President Ulysses S. Grant, broke the bribery story in September, 1872 (Bain 1999, 599-600, 602, 627-28, 676).

${ }^{3}$ Examples include "The Telegraph Combination," New York Times, 22 Aug. 1877, p. 8; "More Trouble for Gould: Metropolitan Stockholders to Have an Inning," New York Times, 5 Nov. 1882, p. 7; "He Shot Me Like a Dog," New York Times, 29 Dec. 1883, p. 4; "Accused of Conspiracy: A Blow at Jay Gould and his Friends," New York Times, 3 Mar. 1885, p. 2; "The Pennsylvania Interested: The Fight for the Cincinnati, Hamilton and Dayton," New York Times, 3 May 1885, p. 2.

${ }^{4}$ For examples of cases involving such contracts, see Smith v. Poor, 40 Me. 415 (1855); March v. Eastern Railroad, 40 N.H. 548 (1860); Flint and Pere Marquette Railway v. Dewey, 14 Mich. 477 (1866); Ashhurst's Appeal, 60 Pa. 290 (1869); Brewer v. Boston Theatre, 104 Mass. 378 (1870); Faulds v. Yates, 57 Ill. 416 (1870); European and North American Railway Co. v. Poor, 59 Me. 277 (1871); Kelly v. Newburyport and Amesbury Horse Railroad, 141 Mass. 496 (1886); Warren v. Para Rubber Shoe Co., 166 Mass. 97 (1896); and Burden v. Burden, 159 N.Y. 287 (1899). See also the much more extensive list of cases in Marsh 1966 and Mark 2003.

${ }^{5}$ For examples of cases involving charges of excessive compensation, see Dunphy v. Traveller Newspaper Association, 146 Mass. 495 (1888); Brown v. De Young, 167 Ill. 549 (1897); Von Arnim v. American Tube Works, 188 Mass. 515 (1905); Abbott v. Harbeson Textile Co., 147 N.Y.S. 1031 (1914); Cole v. Wells, 224 Mass. 504 (1916); Almy v. Almy, Bigelow \& Washburn, 235 Mass. 227 (1920).

${ }^{6}$ For examples of cases involving such charges, see Peabody v. Flint, 88 Mass. 52 (1863); Converse v. United Shoe Machinery, 185 Mass. 422 (1914); and Bonner v. Chapin National Bank, 251 Mass. 401 (1925). For a more extensive list of cases, see Carney 1980. These kinds of manipulations were more likely to make the newspapers, as, for example, when the directors and controlling shareholders of the Brush Electric Company of
} 
other actions that benefited themselves at the expense of their associates. Examples included lending themselves corporate funds, issuing themselves additional shares of stock, and settling law suits against their companies that they themselves had helped to bring. ${ }^{7}$

Minority shareholders had only limited ability to protect themselves against abuses of these types. Standard corporate governance rules based on the principle of one-vote-per-share meant that shareholders who possessed enough stock to decide elections were effectively dictators. ${ }^{8}$ If the majority pursued policies that members of the minority thought were wrongheaded or detrimental to their interests, in the absence of outright fraud there was little that the latter could do. Minority shareholders could not make the majority change their policies. Nor could they force a dissolution of the enterprise. Nor could they easily exit by selling their equity. Even if their firm's shares were publicly traded, they would only be able to sell off their holdings at a price discounted to reflect the majority's behavior. Moreover, in the case of closely held corporations, often the only buyers for their shares were the same majority shareholders with whom they were in conflict.

The intriguing puzzle is that, despite these problems, business people kept forming corporations and minority shareholders kept investing in them. George Heberton Evans, Jr., has

Cleveland, Ohio, arranged to sell their stockholdings to businessmen who controlled the Thomson-Houston Electric Company for $\$ 75$ a share. The par value of the stock was $\$ 50$, and its market price was estimated at that time to be \$35. Minority shareholders were outraged that they were not included in the deal. New York Times, 21 Jan. 1890, p.1.

${ }^{7}$ For examples of cases involving such charges, see Hersey v. Veazie, 24 Me. 9 (1844); Smith v. Hurd, 53 Mass. 371 (1847); Abbott v. Merriam, 62 Mass. 588 (1851); Leslie v. Lorillard, 110 N.Y. 519 (1888); Continental Securities v. Belmont, 133 N.Y.S. 560 (1912); Dunlay v. Avenue M Garage \& Repair Co., 253 N.Y. 274 (1930). A less venal example involved Col. Elliott F. Shepard, who bought control of the Fifth-Avenue Transportation Company for religious reasons in order to stop the running of stages on Sundays, evoking protests from minority shareholders who objected to the loss of revenues. New York Times, 10 May 1888, p. 5.

${ }^{8}$ For a more extensive discussion of the importance of these rules, see Lamoreaux and Rosenthal 2004 and Lamoreaux 2004, which show that the courts made it difficult for firms in the U.S. to adopt non-standard governance rules. For a comparison of voting rules in U.S. corporations with those in corporations in other countries, see Dunlavy 2004. 
counted the number of corporate charters granted in a sample of key states and found a steady rise between the Civil War and the Great Depression. The increase was so steep that Evans's index of incorporations $(1925=100)$ had a value of only about 5 in 1870. In Ohio, for example, the number of charters increased from an average of 305 per year during the 1870s, to 1,166 per year from 1895-1904, to 4,047 per year during the 1920s. ${ }^{9}$ Although the growth was most rapid in the smallest size categories of firms, investors were increasingly willing to risk their savings in large corporations as well. The authorized capital of new Ohio corporations valued at over $\$ 1$ million averaged $\$ 37.6$ million per year in the 1870s. The Ohio figures for later decades are not as informative because large corporations were increasingly choosing to organize first in New Jersey and then in Delaware. In New Jersey, the authorized capital of firms valued at over $\$ 1$ million averaged \$928.4 million per year from 1895-1904, and in Delaware, the comparable annual average was $\$ 18,814.2$ million by the 1920s (Evans 1948, Appendix 3). As Mary O'Sullivan has shown, moreover, relative to GDP the value of new corporate equity issues on the New York Stock Exchange rose between the late nineteenth and early twentieth centuries to levels that, even without the boom years of the late 1920s, were higher than those in the second half of the twentieth century, when the Securities and Exchange Commission protected investors in publicly traded corporations (O’Sullivan 2004).

The shear magnitude of these numbers would seem to indicate that fear of expropriation did not significantly deter investment in corporations during this period. These numbers are not the whole story, however, for large numbers of partnerships also formed during these years. Reliable data are not available until 1900, when the Census of Manufacturers reported

\footnotetext{
${ }^{9}$ The trend seems to have been unaffected by the imposition of the income tax in 1916 , which subject investors in corporations to double taxation.
} 
information on organizational form, but at that time, 67 percent of all U.S. manufacturing establishments owned by more than one person were organized as partnerships and only 29 percent as corporations, with the remaining 4 percent consisting mainly of cooperatives (U.S. Census Office 1902, 503). ${ }^{10}$ Although partnerships on average were significantly smaller than corporations (the Census valued the total product for partnerships at $\$ 2.57$ billion, as opposed to $\$ 7.73$ billion for corporations), their numerical dominance is highly suggestive. The literature has generally treated partnerships as an inferior organizational form, one that mainly had utility for law firms and other similar businesses that depended on specialized human capital for their success (Alchian and Demsetz 1972; Gilson and Mnookin 1985; Grossman and Hart 1986; Hart 1995; Cai 2003; Rebitzer and Taylor 2004). The high proportion of partnerships in the manufacturing sector raises the question of whether business people were deliberately choosing a suboptimal form in order to avoid the governance problems associated with corporations.

We address this question by exploring the decision to organize a new firm as a corporation or a partnership. In sections 2 and 3, we show that the legal rules governing these two forms meant that each alternative was subject to a different organizational problem. In the case of partnerships, the ability of any member of the firm to force a dissolution meant that partners were potentially subject to holdup. In the case of corporations, the power that controlling shareholders possessed to make decisions unilaterally meant that they could capture more than their fair share of the enterprise's returns. We develop a simple model of these alternative problems and show that the willingness of investors to participate in corporations, as

\footnotetext{
${ }^{10}$ Economy-wide counts are not available until after 1916, when the Internal Revenue Service began to collect the income tax. In 1920, there were approximately 314,000 corporations in the United States compared to about 241,000 partnerships, but it is likely that these figures greatly understate the total number of partnerships because all corporations, however small or unprofitable, were required to file tax returns whereas partnerships only had to file if their income exceeded the threshold for the tax. (U.S. Internal Revenue Service 1922, 8-10).
} 
opposed to partnerships, was indeed affected by the extent to which their returns could be expropriated by controlling shareholders. We also show that investors' willingness to join a partnership, rather than not participate in the enterprise at all, was a function of the probability that a dispute among the partners would lead to a premature dissolution of the firm.

In Section 4 we explore the limits that the legal system placed on the share of profits that controlling shareholders could engross. We find that, if anything, these restraints became laxer over the course of our period. Nonetheless, this change probably had little adverse effect on the pace of economic growth. The implication of our model is that organizational problems would only dissuade investors from putting their funds in firms whose expected returns were low. Because there was an abundance of good, highly profitable projects in the U.S. during the late nineteenth and early twentieth centuries, investors willingly participated in the formation of large numbers of new enterprises, including an increasing number of corporations.

\subsection{Partnerships and the Problem of Untimely Dissolution}

Under Anglo-American common law, partnerships were not legal persons and thus had no existence or identity that was independent of the specific individuals who formed them. Each partner possessed full ownership rights and, without consulting the other partners, could enter into contracts that were binding on the firm so long as those contracts were within the scope of the firm's normal business activities. Not only was this right to act unilaterally in and of itself a potential source of conflict within the firm, but it also meant that partners (all of whom were unlimitedly liable for the firm's debts) faced obligations that were beyond their control or perhaps even beyond their knowledge. Because business people would not willingly enter into 
such relationships unless they could extricate themselves when their partners proved untrustworthy, partnerships typically existed only "at will." That is, any member of the firm could force a dissolution simply by deciding that he or she no longer wanted to be part of the enterprise. $^{11}$

As a result, partnerships potentially suffered from what we label the problem of untimely dissolution. Because each partner had full ownership rights and could act without consulting the others, there was a high probability that disagreements would arise that might induce one member of the firm to dissolve the enterprise. Such disagreements were potentially costly. At the very least, they might disrupt the functioning of what otherwise had been a profitable enterprise. More ominously, they might require the liquidation of firm-specific assets at prices below their value had the enterprise been able to continue. Because dissolution was so potentially costly, the at-will character of partnerships created opportunities for hold-up. That is, a partner could attempt to extract a greater share of the firm's revenue just by threatening dissolution. $^{12}$

It was not possible for members of partnerships to commit credibly not to hold up their associates. Although they could sign contracts that specified that the firm would continue for a

\footnotetext{
${ }^{11}$ There are a number of treatises detailing the law of partnership during this period, but see especially Story 1859 and Gillmore 1911.

${ }^{12}$ To give an early example, E. I. Dupont's partner, Peter Bauduy, attempted to boost his share of the firm's income by demanding to count as part of his contribution to capital a note he had endorsed for the benefit of the enterprise. Bauduy threatened dissolution and "could not be pacified" except by a new contract in which he "exacted from the concern some extra compensation and advantages." See "Answer of Eleuthere Irénée Dupont made in his own name as well as in behalf of Mess. E. I. Dupont de Nemours \& Co. to the bill filed in chancery by Peter Bauduy against him and the said concern," 1817, Special Papers, Bauduy Lawsuit (Part I) (1805-1828), Longwood Mss., Box 45, Accession Group 5, E. I. du Pont de Nemours \& Co., Series C, Hagley Library Manuscript Collections, Wilmington, Del.

For a more general discussion of hold-up in partnerships, see Bodenhorn 2002. Bodenhorn argues that individuals mitigated this problem by selecting as partners individuals of similar age, productivity, and capital. We do not deny that business people adopted a variety of strategies to reduce the likelihood of holdup, but the large number of dissolution suits in the legal record and the short lifespan of most partnerships suggests that the problem of untimely dissolution was very real.
} 
fixed term, the courts found it difficult to enforce such agreements with any degree of consistency. Judges were certainly aware that the threat of dissolution could be used as a weapon by one member of the firm to hold up the others. In the words of an Illinois justice, "it would be inequitable to allow [such a person] advantage from his own wrongful acts," especially because "the results flowing from the premature dissolution of a partnership might be most disastrous to a partner who had embarked his capital in the enterprise" and who had been innocent of any "wrongful act or omission of duty" (Gerard v. Gates, 84 Ill. 121 at 125 [1876]). Indeed, some courts refused to allow dissolution if the complaining party was the cause of the dispute among the partners. Thus, in Hannaman $v$. Karrick, a Utah justice insisted that a partner should not be "allowed to ruin the business of the firm from mere caprice, or of his own volition, without cause, and in violation of his agreement, and sacrifice the entire object of the partnership" (9 Utah 236 at 241 [1893]).

The problem, however, was that the courts also generally agreed that firms should be dissolved in situations where, regardless of the cause, "want of confidence and distrust [among the partners] has arisen ..., provided it has become such as cannot probably be overcome" (Sieghortner v. Weissenborn, 20 N.J. Eq. 172 at 178 [1869]). Because "a copartnership is in its essence a contract of agency" in which "each partner is the general agent of the firm, and the firm is the agent of each partner, with power to bind him to a personal liability in favor of partnership creditors," its success necessarily depends on "personal confidence, and when this is wanting [a partnership] can seldom be long maintained with advantage to any party in interest" (Lapenta v. Lettieri, 72 Conn. 377 at 383 [1899]). For this reason, many judges thought that it made little sense to force a partner to continue in business with his associates against his or her will. Indeed, some courts worried that restrictions on dissolution might themselves be pernicious 
and went so far as to declare that the right to dissolve a partnership at will could not be contracted away. Quoting an early New York decision, for example, the Michigan Supreme Court asserted that "there can be no such thing as an indissoluble partnership." To rule otherwise would be to be to expose a member of the firm to the opportunism of his or her associates. "The power given by one partner to another to make joint contracts for them both, is not only a revocable power, but a man can do no act to divest himself of the capacity to revoke it" (Solomon v. Kirkwood, 55 Mich. 256 at 259-60 [1884], citing Skinner v. Dayton, 19 Johns. 513 at 538 [N.Y. 1822]).

Partners victimized by threats of untimely dissolution were not without legal recourse, but the remedy offered by the courts that promoted this view-and that was written into the Uniform Partnership Act in the second decade of the twentieth century (Richards 1921) — was to sue for breach of contract rather than force a continuation of the firm. A partnership agreement was thus to be treated like any other contract: it could "be broken at pleasure, subject however to responsibility in damages" (Solomon v. Kirkwood, 55 Mich. 256 at 260 [1884]). Objecting to this view, the Utah court complained that such a remedy could never provide "complete justice" to the aggrieved party for, not only was "this mode of redress . . . usually slow and unsatisfactory," but the resulting "damages, in many cases, must necessarily prove to be utterly inadequate to compensate for the destruction of a profitable and growing business" (Hannaman v. Karrick, 9 Utah 236 at 241-42 [1893]). Although this criticism was undoubtedly correct, it did not carry the day. Indeed, the U.S. Supreme Court criticized the Utah justice's position, asserting that the only difference "so far as concerns the right of dissolution by one partner" between partnerships at will and those for specified terms was that "in the former case, the dissolution is no breach of the partnership agreement, and affords the other partner no ground of 
complaint," whereas in the latter "such a dissolution before the expiration of the time stipulated is a breach of the agreement, and as such to be compensated in damages" (Karrick v. Hannaman, 168 U.S. 328 [1897]). ${ }^{13}$

By defining some attempts to dissolve partnerships prematurely as illegitimate breaches of contract punishable by an award of damages, the legal rules embodied in the Uniform Partnership Act put limits on partners' ability to increase their wealth by holding each other up. Short of a systematic study of damage awards at the lower-court level, there is no way of knowing exactly what these limits were in actual practice. Nonetheless, it is doubtful that they declined over time. ${ }^{14}$ Indeed, if anything, it is likely that the net effect of this legislation was to establish with greater certainty the principle that all partnerships, even those to which the members had committed themselves for a fixed term, were dissolvable at will.

\subsection{A Simple Model of Partnerships}

In order to obtain a better understanding of the consequences of the at-will character of partnerships for business people's willingness to participate in otherwise profitable enterprises, we model the partnership form of organization as suffering from the probability that a

${ }^{13}$ This case is particularly interesting for Justice Gray of the U.S. Supreme Court went out of his way to criticize the Utah court's decision in Hannaman v. Karrick, even though he admitted that it was not necessary for the adjudication of the appeal for him "to express an opinion upon this point." After reviewing the relevant case law, Gray concluded that he was "not prepared ... to assent to the opinion of the court below that a partnership for a definite time cannot be dissolved by one partner at his own will, and without the consent of his copartner" (Karrick v. Hannaman, 168 U.S. 328 at 336 [1897]). Although partnerships were normally matters of state rather than federal law, this case was appealed to the U.S. Supreme Court because Utah was still a territory under federal authority. It should be noted that in such matters, unlike Constitutional issues, the U.S. Supreme Court did not make law for the nation. Nonetheless, the decision of such a prestigious court carried enormous weight.

${ }^{14}$ The relatively few cases involving damage assessments reported at the appeals-court level suggest that there was no significant change over time in the legal principles that governed such awards. Compare, for example, Bagley v. Smith, 10 N.Y. 489 (1853) with Zimmerman v. Harding, 227 U.S. 489 (1913). 
disagreement or hold-up attempt among the partners will lead to an untimely dissolution of the firm. Imagine a firm whose total return per unit of capital, $\mathrm{R}$, is

$$
\mathrm{R}=\mathrm{p} \Pi+(1-\mathrm{p}) \alpha \Pi
$$

where $\mathrm{p}$ is the probability that the firm succeeds $(0<\mathrm{p}<1), \Pi$ is the firm's earnings if it is successful, and $\alpha \Pi$ is the liquidation value of the firm if it fails $(0<\alpha<1)$. In order to keep the analysis simple, we assume (without any loss of generality) that $\mathrm{p}$ and $\alpha$ are the same for all firms - that is, firms only differ in the magnitude of the profits they can earn. We also assume that there is no asymmetric information and that members of firms are not risk averse. Furthermore, we assume that a firm consists only of an entrepreneur and an investor, each of whom contributes capital $\left(\mathrm{K}=\mathrm{K}_{\mathrm{E}}+\mathrm{K}_{\mathrm{I}}\right)$, though we relax this assumption later on.

If the firm is organized as partnership, the two participants face costs associated with the probability that an otherwise successful enterprise will be forced to dissolve. We take this probability (d) to be given exogenously by the existing legal rules and by the existence of social institutions, such as the family or the community, that help govern relations among partners. If the firm is organized as partnership, then its return on capital, $R_{P}$, is:

$$
\mathrm{R}_{\mathrm{P}}=\mathrm{p}(1-\mathrm{d}) \Pi+\mathrm{pd} \alpha \Pi+(1-\mathrm{p}) \alpha \Pi
$$

Both the entrepreneur and the investor earn the same return as the firm. $\left(R_{P E}=R_{P I}=R_{P}\right.$, where $R_{P E}$ and $R_{P I}$ are the returns to the entrepreneur and to the investor respectively.) Both therefore face same participation constraint. That is, they will only participate in the enterprise if they expect to be able to earn at least as much as they could in the market- that is, $1+\mathrm{r}$ :

$$
\mathrm{R}_{\mathrm{PE}}=\mathrm{R}_{\mathrm{PI}}=\mathrm{p}(1-\mathrm{d}) \Pi+\mathrm{pd} \alpha \Pi+(1-\mathrm{p}) \alpha \Pi>1+\mathrm{r}
$$


The implications of these participation constraints are apparent if we take $\mathrm{p}, \alpha$, and $\mathrm{r}$ as given. As Figure 1 illustrates, for each $\Pi$ there is a unique $\mathrm{d}^{*}$ (represented by the top upward sloping curve) above which no partnerships will be formed.

As this analysis suggests, the partnership form is socially inefficient because the expected return that a firm can earn if it organizes as a partnership is below the return that could be earned if there were no problem of untimely dissolution. Because of this organizational cost, if the partnership were the only available form that business people could choose, many firms that otherwise would be socially efficient will not form. The situation, moreover, is even worse if we relax our assumption that the firm consists of only two partners. If we assume that each associate has an independent probability (d) of forcing a dissolution, then the probability that no dispute will occur is $(1-\mathrm{d})^{\mathrm{n}}$, and the probability of untimely dissolution, D, equals 1-(1-d $)^{\mathrm{n}}$, where $\mathrm{n}$ is the number of partners. As Figure 1 shows, the more partners there are, the more likely it is that profitable business opportunities will go unrealized. By extension, projects that require large amounts of capital, and thus many investors, are unlikely to be undertaken as partnerships.

\subsection{Corporations and the Problem of Minority Oppression}

This unsatisfactory situation captures the essential details of the U.S. business environment in the early nineteenth century. By mid-century, however, most states had responded to the problem of untimely dissolution in partnerships by providing business people with an alternative organizational form: the corporation. ${ }^{15}$ Unlike partnerships, corporations

\footnotetext{
${ }^{15}$ An intermediate form, the joint stock company, had evolved in Britain as a partial solution to the problem of untimely dissolution. Joint stock companies were partnerships that obtained by means of contract some of the features of the corporate form. They were a highly imperfect substitute for corporations, however, and there was a great deal of uncertainty, especially in the U.S., about whether the courts would enforce all the provisions of these
} 
were by definition legal persons whose existence was in no way dependent on the ongoing participation of the people who founded them. Indeed, the identity of each and every one of a corporation's members could change without affecting the continuance of the enterprise (Freund 1896). ${ }^{16}$

Corporations solved the problem of disagreements among members of the firm by making the controlling shareholders effectively dictators. But this solution itself was potentially a source of problems. Because the only members of a corporation who could make decisions were officers who had been duly elected by the shareholders, any coalition that determined the election of officers also controlled the firm. This coalition could then use its power to benefit its members at the expense of other shareholders. Although the latter were only limitedly liable for the enterprise's debts and thus, in most cases, stood to lose no more than their investments, they had no means of preventing the controlling shareholders from expropriating some of their share of the returns.

We conceive of this problem of minority oppression as the main cost associated with the corporate form. Whereas we modeled the return to an investor in a partnership as a function of the profitability of the enterprise and the probability of untimely dissolution, we model the return to an investor in a corporation as a function of the profitability of the enterprise and the extent of these private benefits of control. Before we describe the two alternatives more formally, we offer a historical example as evidence that our stylized version of these two organizational forms

contracts. For an excellent survey of the relevant literature, see Blair 2003. See also Warren 1929 and Harris 2000. Business people in the U.S. could also choose the limited partnership form of organization, but the legislation regulating this option was so restrictive, and the courts so strict in their interpretation, that the form was rarely used. See Lamoreaux and Rosenthal 2004.

${ }^{16}$ Of course, if an associate who had critical human capital withdrew, the business might be more likely to fail. Hence corporations too were potentially subject to holdup. But we assume that this problem was small for corporations compared to partnerships and ignore it in our subsequent analysis. 
captures the way both business people and the courts thought about the choice between partnerships and corporations: the case of Burden v. Burden, decided by the New York Court of Appeals in 1899 (159 N.Y. 287).

The disputants in the case were brothers who had inherited an iron factory from their father in 1871. The brothers operated the business as a partnership for the next ten years, but increasingly disagreed about its management until, by 1881, their relationship had deteriorated to the point where, in the words of the court, they "ceased to hold any personal conversation with each other and discussed their grievances in written communications only" (159 N.Y. 287 at 295). Finally, James A. Burden, the brother who had been trained as an iron master, decided that he could no longer bear the conflict and determined to force either a dissolution of the firm and a division of the property or the reorganization of the firm as a corporation that he would control. His brother, I. Townsend Burden, agreed to the latter option, and the business was incorporated as the Burden Iron Company. James held 1000 shares in the new concern and Townsend, 998. The remaining two shares went to James's associate, John L. Arts, who held a managerial position in the enterprise. In other words, in order to avoid the costs of dissolving a profitable enterprise, Townsend consented to become a minority shareholder in a corporation controlled by his brother. Although he continued to receive half of the profits that the firm paid out in dividends, he was completely frozen out of the management.

Townsend brooded over this outcome for three and a half years and then sued in equity, complaining that his lack of influence in the company had enabled his brother and Arts to run it in a way that was detrimental to his interests. In particular, he charged that "James and Arts [had] combined and conspired together, in violation of their duties as trustees, to the great damage of the Burden Iron Company, and to build up and sustain their own private interests" (159 N.Y. 287 
at 306). Both the trial court and the appeals court were unsympathetic. Writing for the latter, Justice Bartlett acknowledged that "the plaintiff is doubtless quite right when he insists that he has been ignored in the management of the Burden Iron Company, and has no control, save to vote his stock, over properties of great value in which his interest is nearly one-half." But, he pointed out, Townsend "apparently fails to appreciate that his troubles are inherent in the situation." He had voluntarily agreed to give his brother control in order to prevent the untimely dissolution of an enterprise that was profiting them both. Generalizing from Townsend's situation, Bartlett explained that "the plaintiff is in the position of all minority stockholders, who cannot interfere with the management of the corporation so long as the trustees are acting honestly and within their discretionary powers." The plaintiff, he declared, "must submit" (159 N.Y. 287 at 308).

\subsection{Modeling the Choice between Partnerships and Corporations}

Given these starkly posed differences between partnerships and corporations, we return to our basic two-person model and make several additional assumptions. First, because it now matters who owns the largest share of the firm's equity, we assume that the entrepreneur owns more and has control of the firm-that is:

$$
\mathrm{K}=\mathrm{K}_{\mathrm{E}}+\mathrm{K}_{\mathrm{I}} \text { and } \mathrm{K}_{\mathrm{E}}>\mathrm{K}_{\mathrm{I}}
$$

Second, we assume that the entrepreneur's control allows her to steal some fraction $(\omega)$ of the firm's profits, where the magnitude of $\omega$ is exogenously determined, in large measure by the legal system, which defines the boundary at which "private benefits of control" become fraud, but also by social institutions, such as the family or the community, that help govern relations 
among members of the firm. Finally, we assume that stealing affects only the distribution and not the level of the firm's profits, so that the return to a corporation is same as the return to the firm, which is greater than the return to a partnership.

$$
\mathrm{R}_{\mathrm{C}}=\mathrm{p} \Pi+(1-\mathrm{p}) \alpha \Pi>\mathrm{R}_{\mathrm{P}}
$$

Under these assumptions, so long as she can earn at least $1+\mathrm{r}$, the entrepreneur will always want to organize the firm and always as a corporation, because the return to a corporation is higher than that to a partnership and because her ability to steal earns the entrepreneur even more. The investor, however, will only be willing invest in a corporation under the following conditions:

$$
\mathrm{R}_{\mathrm{CI}}=[\mathrm{p}+(1-\mathrm{p}) \alpha](1-\omega) \Pi>1+\mathrm{r}
$$

Taking $\mathrm{p}, \alpha, \omega$, and $\mathrm{r}$ as fixed, then this participation constraint implies there is a unique $\Pi^{*}$ such that investors will only participate in corporations if $\Pi \geq \Pi^{*}$.

If $\Pi<\Pi^{*}$, then firms will only form if they can be organized as partnerships. But entrepreneurs and investors will only be willing to organize partnerships to exploit otherwise attractive opportunities if the probability of untimely dissolution is not too high. That is:

$$
\mathrm{R}_{\mathrm{P}}=\mathrm{p}(1-\mathrm{d}) \Pi+\mathrm{pd} \alpha \Pi+(1-\mathrm{p}) \alpha \Pi>1+\mathrm{r}
$$

If $\Pi \geq \Pi^{*}$, then corporations will be formed if the entrepreneur has the power to choose the form of organization, but for some range of $\Pi$ there will be a conflict between the preferences of the investor and those of the entrepreneur. Investors will prefer to organize the firm as a corporation if $\mathrm{R}_{\mathrm{CI}}>\mathrm{R}_{\mathrm{PI}}$. That is:

$$
(p+(1-p) \alpha)(1-\omega) \Pi>(p(1-d)+((1-p)+d p) \alpha) \Pi
$$

In other words, the investor prefers a corporation if:

$$
\mathrm{d}>\omega(\mathrm{p}+(1-\mathrm{p}) \alpha) /(\mathrm{p}(1-\alpha)
$$


The resulting distribution of organizational forms is displayed in Figures 2 and 3. In Figure 2 we hold $\omega$ fixed and allow d to vary. The vertical line indicates $\Pi^{*}$, the threshold value of $\Pi$ below which corporations cannot form, and the upward sloping line, $d^{*}(\Pi)$, demarcates the boundary above which partnerships cannot form. Similarly, in Figure 3 we fix $\mathrm{d}$ and allow $\omega$ to vary. In this case, $\Pi^{*}$ refers to the threshold value below which partnerships do not form (variation on the vertical axis does not affect them), and the upward sloping line, $\omega^{*}(\Pi)$, defines the feasible area for corporations.

The figures underscore two important implications of our model. First, in equilibrium there is likely to be a demand for both organizational forms. Second, some firms do not form simply because of organizational difficulties. If $\omega$ is big, there will be a large range of firms for which profits are too low to induce investors to participate in a corporation. Whether or not these firms form depends on the magnitude of $\mathrm{d}$. Clearly, therefore, it would be efficient to reduce $d$ and even more salutary to reduce $\omega$. In societies with high transaction costs of these types, improvements in institutions hence can have an important impact on growth. Nonetheless, it should be noted that the firms that do not form are those with relatively low returns. For firms with high enough returns, organizational difficulties are a nuisance but do not affect entry.

\subsection{Extensions of the Model}

In this section, we consider two extensions of the model: the case where the entrepreneur is poor and so owns less of the firm than the investor; and the case where there are more than two members of the firm. In an appendix, we consider a third possibility-that equity shares are endogenous and distinguishable from investment shares. There we consider the possibility that 
the entrepreneur could increase her profit by reducing the investor's equity stake until his return approached that of the market. We also consider the possibility that the entrepreneur could increase the range of profits over which the investor was willing to participate in a corporation by offering him a higher equity stake in order to raise his return. As we show, the entrepreneur would be constrained in pursuing this second strategy by her need to maintain control. Therefore, the closer her initial share to 50 percent, and the higher $\omega$, the more likely the enterprise would organize as a partnership.

Suppose that the entrepreneur is the owner of a scarce asset (for example, an invention), but that she is poor, so $\mathrm{K}_{\mathrm{E}}<\mathrm{K}_{\mathrm{I}}$. This reversal does not change the model so far as partnerships are concerned, because for partnerships the participation constraint is the same for both the entrepreneur and the investor and does not depend on their respective ownership shares. For corporations, however, the change in relative equity stakes means that the investor will now have control. As a result, the investor's return will always be greater than that of the entrepreneur, and it is now the entrepreneur's participation constraint that binds. Because the entrepreneur's participation constraint is identical to that of the investor in the original model, reversing the relative equity stakes of the entrepreneur and investor does not alter the boundary of the region where corporations are feasible. It can, however, alter the entrepreneur's choice of organizational form when both partnerships and corporations are feasible and dissolution costs are low. In particular, if the entrepreneur gets to choose the form of organization and $\Pi \geq \Pi^{*}$ and $\mathrm{d} \leq \omega(\mathrm{p}+(1-\mathrm{p}) \alpha) /(\mathrm{p}(1-\alpha))$, she will now opt for a partnership instead of a corporation. The partnership is less socially efficient than the corporation, but it is the only way, in the environment that we have constructed, for the entrepreneur to protect herself from the 
expropriation that loss of control entails. The consequence is that she, the investor, and society will have to bear the costs associated with untimely dissolution in partnerships.

Suppose now that there are multiple investors in the corporation. If the entrepreneur retains control (that is, if the entrepreneur owns a majority of the stock in her own right or is part of a binding coalition that collectively owns a majority share), then the analysis is the same as in the basic model. If there is a controlling coalition, but the entrepreneur is not a member of it, then the case is like that of the poor entrepreneur just described (though as the number of members of the firm grows large, and therefore partnerships become comparatively more costly, one would expect the entrepreneur instead to insist on membership in the governing coalition). In other words, the only significant deviation from our model occurs in situations where there is no predetermined group or individual that has control. We can conceive of this case theoretically by imagining that every member of the firm, including the entrepreneur, has an equal chance ex ante of being part of the governing coalition. Because everyone is equally likely to end up in a situation where s/he can extract private benefits of control, everyone has the same expected return which is equal to the firm's return. This type of a corporation would always be chosen over a partnership.

The entrepreneur, however, would always prefer to be sure that she would be part of a controlling coalition because in that way she could obtain the private benefits that derive from control. If the relationship between the entrepreneur and the other members of the coalition was such that contractual guarantees of the group's stability were needed, there was a readily available mechanism in the form of a voting trust. Moreover, there was little uncertainty about 
the enforceability of such contracts, because voting trusts repeatedly were upheld by the courts. ${ }^{17}$ One might expect, therefore, to find coalitions formed to control firms wherever profits were high enough to induce outside investors to participate. Where profits were too low to attract participation, one would expect the entrepreneur to forego her certainty of control rather than form a less efficient partnership. Such forbearance, however, would only be feasible if there were at least three principals. If there were just two, one would inevitably have control, and the only solution to minority oppression would be a partnership.

\section{Trends in the Limits on Private Benefits of Control}

As we have already seen, despite the costs potentially imposed on investors by majority shareholders' private benefits of control, increasing numbers of corporations were formed during the late nineteenth and early twentieth centuries, and increasing numbers of investors willingly purchased their shares. One possible explanation for these trends is that the legal system placed additional constraints on the ability of controlling shareholders to deflect returns in their direction — that is, reduced the magnitude of $\omega$. As we shall see, however, the changes that occurred during this period in the legal rules governing corporations appear to have worked in the opposite direction.

Just as the courts recognized that there was a problem of holdup in partnerships, they understood that minority shareholders in corporations were vulnerable to exploitation by the majority. But they faced two important problems that prevented them from offering the former much in the way of protection. The first was that minority shareholders did not have standing

\footnotetext{
${ }^{17}$ See, for examples, Brown v. Pacific Mail Steamship Co., 4 F. Cas. 420 (1867); Faulds v. Yates, 57 Ill. 416 (1870); Brightman v. Bates, 175 Mass. 105 (1900); Manson v. Curtis, 223 N.Y. 313 (1918).
} 
under the common law to redress their grievances by suing corporate officers and directors who abused their positions. Corporations were legal persons, and as a result, only they and not their shareholders could initiate legal action. ${ }^{18}$ Although abusers who were in positions of control were unlikely to allow their corporations to sue themselves, this problem was relatively easily surmounted by granting minority shareholders the right under certain circumstances to pursue a case in own names in a court of equity, rather than at common law. The key precedent was Robinson v. Smith (3 Paige 222 [1832]), in which New York's Chancellor explicitly extended to business corporations principles of trusteeship that had previously been used to protect beneficiaries of charitable entities. The Chancellor posited that the directors of a corporation were equivalent to trustees and that the stockholders, having a joint interest in the corporation's property, were "cestui que trusts." Declaring that equity courts never permit wrongs "to go unredressed merely for the sake of form," he indicated that the stockholders might, after demonstrating that the corporation was controlled by those who were abusing their trust, file a bill in their own names, "making the corporation a party defendant."19

The second and more difficult problem that the courts faced was to protect minority shareholders without undermining the legal differences between corporations and partnershipsthat is, without creating a situation in which disagreements among members of the firm could

${ }^{18}$ This principle underpinned the decision of Chief Justice John Marshall of the U.S. Supreme Court in Dartmouth College v. Woodward (17 U.S. 518 [1819]). Massachusetts Supreme Court Justice Lemuel Shaw explicitly articulated its implications for minority shareholders in Smith v. Hurd in 1847: "The individual members of the corporation, whether they should all join, or each severally, have no right or power to intermeddle with the property or concerns" of the firm. They also have no power to "call any officer, agent or servant to account." If there was an injured party, it was the corporation, the legal person whose rights were at stake, and only the corporation itself could take action to redress the damage (53 Mass. 371 at 384-87). For a similar English case, see Franks, Mayer, and Rossi 2004.

${ }^{19}$ For a more complete discussion of this case, as well as the Dartmouth College v. Woodward and Smith $v$. Hurd decisions, see Bloch and Lamoreaux 2004. That there was a similar trend in English law can be seen from the cases cited in Robinson v. Smith and also in the later U.S. Supreme Court decision, Dodge v. Woolsey, 59 U.S. 331 (1856). 
disrupt the functioning of corporations as easily as they did partnerships. For this reason, the courts were very conservative in defining what constituted an abuse of trust by those in control. For example, they quickly settled on the principle that shareholders could not sue officers and directors of corporations simply because they pursued policies that the former thought were wrongheaded or disadvantageous. Such disagreements were matters of business judgment and, as such, beyond the purview of the courts. Hence when Thomas A. Edison sought to force the Edison United Phonograph Company to adhere to his own sense of how the business should be conducted by suing in equity to have the directors removed, the court rebuffed his request: "No rule of law is better settled than that which declares that, so long as the directors of a corporation keep within the scope of their powers and act in good faith and with honest motives, their acts are not subject to judicial control or revision" (Edison v. Edison United Phonograph Co., 52 N.J. Eq. 620 [1894]). Unless the directors had clearly exceeded their statutory powers, the courts were unwilling to intervene in the affairs of a solvent corporation without compelling evidence that those in control had engaged in fraudulent or illegal acts that had inflicted serious damage on the corporation or its shareholders. Moreover, the burden of proof was on the shareholders bringing the suit. As the Massachusetts Supreme Court explained in the oft-cited case of Dunphy v. Traveller Newspaper Association, "it is always assumed until the contrary appears, that [directors] and their officers obey the law, and act in good faith towards all their members" (146 Mass. 495 at 497 [1888]).

That this interpretation of the Robinson $v$. Smith precedent operated to increase the magnitude of $\omega$-that is, the private benefits that controlling shareholders could extract from their associates - is suggested by the changing way in which courts responded to situations in which directors had conflicting interests. There was a long-established principle of law that 
contracts tainted by conflicts of interest were voidable. This rule was an absolute one and applied to contracts that otherwise seemed completely reasonable, so that even though "the contract could not have been let on better terms, . . the principle of law applicable to such a contract renders it immaterial ... whether there has been any fraud in fact, or any injury to the company" (Flint \& Pere Marquette Railway Company v. Dewey, 14 Mich. 477 [1866] at 48788). Moreover, there is no question that the principle applied to corporations, as the U.S. Supreme Court emphatically affirmed in 1880 in Wardell v. Railroad Company, a case that arose as a result of a contract that officers of the Union Pacific Railroad had negotiated with a coal company that they themselves had organized. Writing for the Court, Justice Field declared: Directors of corporations, and all persons who stand in a fiduciary relation to other parties, and are clothed with power to act for them, are subject to this rule; they are not permitted to occupy a position which will conflict with the interest of parties they represent and are bound to protect. They cannot, as agents or trustees, enter into or authorize contracts on behalf of those for whom they are appointed to act, and then personally participate in the benefits (103 U.S. 651 [1880] at 658).

In this particular case, however, the action to void the contract was taken in the name of the corporation, whose directors had never formally approved it (the agreement had been drawn up and executed by the road's executive committee and had not been submitted to the board). Hence the justices did not have to consider what the outcome of their decision would have been if the suit had been brought by a minority shareholder. The cases Field cited in his decision suggest the outcome might well have been different, ${ }^{20}$ and, indeed, there is evidence that state

\footnotetext{
${ }^{20}$ For example, Flint and Pere Marquette Railway v. Dewey was brought by a corporation whose directors had ratified a contract proposed by the company's president without knowing that the president stood to profit from
} 
courts had for some years been applying what was in effect a reasonableness standard in such circumstances. For example, in the frequently cited case of Hodges v. New England Screw Company, the Rhode Island Supreme Court refused to invalidate the sale of assets by one corporation to another that was controlled by essentially the same people, determining that the plan was "judicious, and for the interest of the Screw Company" (1 R.I. 312 [1850] at 343). Moreover, the very next year after its Wardell decision, the U.S. Supreme Court established in the case of Hawes v. Oakland what was in effect a reasonableness standard. A stockholder victimized by such a conflict of interest could "sustain in a court of equity in his own name" in the case of:

a fraudulent transaction completed or contemplated by the acting managers, in connection with some other party, or among themselves, or with other shareholders as will result in serious injury to the corporation, or to the interests of the other shareholders; Or where the board of directors, or a majority of them, are acting for their own interest, in a manner destructive of the corporation itself, or of the rights of the other shareholders; Or where the majority of shareholders themselves are oppressively and illegally pursuing a course in the name of the corporation, which is in violation of the rights of the other shareholders . . . (our emphasis, Hawes v. Oakland, 104 U.S. 450 [1881] at 460). ${ }^{21}$

\footnotetext{
the arrangement. In its decision, the court raised the possibility that the contract might possibly be construed as binding if it had been ratified by the board "after a full explanation and knowledge of their interest and of all the circumstances" (14 Mich. 477 [1866] at 487).

${ }^{21}$ In this decision the Supreme Court was deliberately qualifying a more liberal standard that it had articulated in the 1856 case of Dodge v. Woolsey, 59 U.S. 331. The qualification was a response to a flood of lawsuits that the earlier decision had stimulated and hence a good example of how the courts attempted to balance, on the one hand, their effort to limit the extent of the private benefits of control with, on the other, their desire not to encourage rent seeking by minority shareholders. For further discussion of these cases, see Bloch and Lamoreaux 2004.
} 
As the phrases we italicized indicate, in order to secure the intervention of the courts, minority shareholders had to demonstrate that the actions taken by those in control were both fraudulent and seriously injurious.

Not only did the courts burden complaining shareholders with the task of proving that a contract tainted by conflict of interest was unreasonable, but there is evidence that they tended to give the controlling group the benefit of the doubt on the grounds that its members were unlikely deliberately to take actions that eroded the value of their own stock. Hence the Rhode Island court asserted in the case of Hodges v. New England Screw Company, "we are the more confirmed in [our conclusion that the sale of assets was appropriate], when we recollect that the directors owned a large majority of the capital stock of the Screw Company, and could not reduce the plaintiff's stock, without, at the same time, and in the same proportion, reducing the value of their own" (1 R.I. 312 [1850] at 343-44). Similarly, in Faud v. Yates, the Illinois Supreme Court found nothing wrong with a partnership agreement entered into by three stockholders of the Chicago Carbon and Coal Company. Collectively the three held a majority of the corporation's stock, and their agreement committed them to cast their votes in a block so that they could control the election of the board of directors. The partnership also leased the company's coal lands and operated its mines. In the view of the court, "The record wholly fails to disclose any injury to the other shareholders - any waste of the property," and therefore there was no reason to invalidate the agreement. But the court went even further and asserted that there was no conflict of interest involved because the incentives of the partners and of other shareholders were aligned. The partners, according to the court "had a double interest to protect,- - their interests as shareholders, and their interests as lessees.... As shrewd, skillful and prudent men, they were desirous of increasing the investment, and making the stock more 
valuable. Their interests were identical with the interests of the minority shareholders" (57 Ill. $416[1870]$ at $420-21)$.

The courts were willing to intervene in cases where conflicts of interest led to contracts that were demonstrably fraudulent. This willingness placed limits on $\omega$, but it is important to underscore that the shift was from a situation in which the courts would always permit such contracts to be voided to one in which complaining shareholders had to clear significant hurdles in order to obtain redress. It is difficult to get a precise idea of how high the hurdles were in actual practice without systematically studying the dispensation of cases at the lower-court level. We can, however, obtain some sense of the standards the courts applied from the case law. For example, one way in which plaintiffs could make the case that contracts tainted by conflicts of interest were fraudulent was to submit evidence that the resulting payments were substantially in excess of market levels. Hence Townsend Burden lost his case against his brother James in part because he was unable to show that James had paid too much for iron ore purchased from another company that he controlled. The trial court concluded that there was no evidence that these purchases were "made in bad faith or with any intent to defraud," but to the contrary that they had saved the Burden Iron Company money (Burden v. Burden, 159 N.Y. 287 [1899] at 306).

Even with such proof, complaining stockholders were in a much stronger position if they could also show that the controlling group had knowingly behaved improperly. Otherwise, their grievance was liable to be dismissed because the courts agreed that "mere errors of judgment are not sufficient as grounds for equity interference; for the powers of those entrusted with corporate management are largely discretionary" (Leslie v. Lorillard, 110 N.Y. 519 at 532 [1888]). In Brewer v. Boston Theatre, the plaintiffs were able to make their case that several of the directors 
were fraudulently extracting profits from the corporation by showing that the latter had deliberately concealed their involvement in contracts from the other members of the board (104 Mass. 378 [1870]). Similarly, in Almy v. Almy, Bigelow \& Washburn, the plaintiff was able to document that, after she had refused to sell them her stock, the controlling shareholders had tried to force her out of the company by, among other things, voting excessive salaries "to each and every member of the board, except the plaintiff Almy," as well as voting themselves other "gifts and gratuities" (235 Mass. 227 [1920] at 233).

As these last cases suggest, the courts did intervene in corporations and punish controlling shareholders who exploited their position to the detriment of other owners. Before they were willing to act, however, judges demanded compelling evidence of misdeeds. In Flint and Pere Marquette Railway v. Dewey, the Michigan Supreme Court had warned that if selfdealing contracts "were held valid until shown to be fraudulent and corrupt, the result, as a general rule, would be that they must be enforced in spite of fraud and corruption" (14 Mich. 477 at 488). That prophesy was borne out by the late nineteenth century. Although $\omega$ was bounded, it was positive and nontrivial. Moreover, its magnitude seems if anything to have increased over our period.

\section{Conclusion}

Partnerships and corporations each suffered from a different organizational problem. Because partnerships effectively existed only at the will of each of the members of the firm, they suffered from the potentially costly problem of untimely dissolution. That is, disagreements among members of a firm could lead one of the partners to withdraw from the enterprise, 
disrupting the operations of an otherwise profitable business and perhaps necessitating the liquidation of firm-specific assets. This problem probably grew worse over the course of the late nineteenth and early twentieth centuries because changes in the legal rules underscored the atwill character of partnerships, establishing with greater certainty the principle that all partnership contracts, even those for fixed terms, were revocable. The greater the number of partners, the greater the problem. Indeed, if partnerships had been the only available organizational form during this period, it is likely that it would have been extremely difficult to raise equity in the sums necessary for large-scale capital-intensive enterprises.

But partnerships were not the only available organizational form. By the mid-nineteenth century business people in most states could readily organize their enterprises as corporations instead. Although disagreements among members of the firm could and did arise in corporations as well as in partnerships, the rules of corporate governance gave controlling shareholders what were in effect dictatorial powers. Majority shareholders could ignore the complaints of the minority if they so chose, and the latter had little choice but to grin and bear it. Members of the minority could not impose their will on the controlling shareholders; nor could they force a dissolution of the enterprise. This protection against untimely dissolution, however, came at a significant cost, for the same dictatorial authority that allowed the majority to disregard the views of the minority also gave controlling shareholders the power to expropriate more than their fair share of the company's earnings.

Although the media periodically published dramatic revelations of shenanigans by groups in control of corporations (aside from the Crédit Mobilier scandal, perhaps the most famous was Charles Francis Adams's account, Chapters of Erie [Adams and Adams 1871]), there appears to have been no major groundswell for reform until fallout from the 1929 stock market crash 
provoked Congress to create the Securities and Exchange Commission in 1934. Even then, however, the legislation applied only to large publicly traded corporations, and minority investors in privately held firms remained largely unprotected. There is some indication that by the 1930s judges had become more receptive to shareholders' complaints than was the case earlier (Marsh 1966; Mark 2003), but major changes in the status of investors in private corporations would only come during the post-World War II period, when states began to revise their general incorporation statutes and pass new legislation giving minority shareholders greater access to the courts (O'Neil 1978; Hillman 1982). Yet another wave of legislation at the end of the twentieth century provided small businesses with access to alternative organizational forms, most notably the limited partnership (LLP) and the limited liability company (LLC) (Lamoreaux and Rosenthal 2004).

If protecting outside investors was unequivocally a good thing, one might expect the law to have evolved much more quickly in ways that increased minority shareholders' ability to defend themselves against expropriation by those in control of corporations. As we have seen, however, the changes that occurred in the law appear to have had precisely the opposite effect during the late nineteenth and early twentieth centuries. Because judges were intent on preventing disputes among members of the firm from disrupting the operation of corporations the way they did partnerships, they were not willing to allow disgruntled shareholders easy access to the courts. In fact, rather than give shareholders a legal weapon to use against corporate officers and directors, judges preferred to emasculate the long-standing common-law rule that contracts in which one party had a conflict of interest were voidable per se.

Although we have no way of estimating the magnitude of the private benefits that controlling shareholders could extract from their corporations without running afoul of the law, 
the legal record suggests that they were quite high. If they were low, moreover, we should have observed a steep decline in the number of partnerships during this period. Not only was there no such fall, but large numbers of partnerships continued to be formed. At the same time, the number of corporations also evinced a steady rise, as did investors' willingness to put their money in corporations. ${ }^{22}$ Given that $\mathrm{d}$ and $\omega$ were probably increasing rather than decreasing, the high rate at which firms were forming during the late nineteenth and early twentieth centuries is most likely attributable to the availability of large numbers of good (high profit) projects. Everything that we know about this period of U.S. history - the rapid population growth, fall in transportation and communications costs, settlement of the continent, discovery of raw material resources, and dramatic pace of technological change-suggests that attractive entrepreneurial opportunities were indeed abundant. Many of these opportunities required capital in amounts sufficient to exploit economies of scale, making it especially important to have access to a form that would not suffer disruption as the number of investors increased. To the extent that these large projects also yielded returns that were high relative to government bonds or other similar assets, the private benefits of control that majority shareholders were able to extract were more an annoyance than a serious deterrent to investors. The great depression of the 1930s would dramatically alter this calculus, disrupting the legal equilibrium of the late nineteenth and early twentieth centuries and setting the economy off on a new path of institutional change, one whose

${ }^{22}$ Although newspaper announcements and other similar sources indicate that large number of partnerships as well as corporations were forming during this period, there are no data that enable us to measure trends in the relative numbers of partnerships and corporations before the income tax was imposed in 1916. The counts of the number of partnerships and corporations that the Internal Revenue Service published in its annual reports, Statistics of Income, indicate that the number of partnerships relative to corporations decreased in the 1920s, held stable in the 1930 s, increased in the 1940s, and decreased in the 1950s. Only the last of these trends probably represented a significant shift in the business people's preferred organizational forms. The others probably owed more to changes in tax levels that forced more (or less) partnerships to file returns. Corporations had to file regardless of whether or not they owed taxes, but partnerships did not. 
outcome would be a set of statutes and precedents that were much more solicitous of the rights of minority investors.

\section{References}

Adams, Charles Francis, Jr., and Henry Adams. 1871. Chapters of Erie and Other Essays. Boston: J. R. Osgood \& Co.

Alchian, Armen A., and Harold Demsetz. 1972. "Production, Information Costs, and Economic Organization.” American Economic Review, 62 (December): 777-95.

Bain, David Haward. 1999. Empire Express: Building the First Transcontinental Railroad. New York: Viking.

Blair, Margaret M. 2003. "Locking in Capital: What Corporate Law Achieved for Business Organizers in the Nineteenth Century." UCLA Law Review, 51 (December): 387-455. Bloch, Ruth, and Naomi R. Lamoreaux. 2004. "The Public-Private Distinction in American History: The Privatization of the Corporation and the Problem of Minority Shareholders." Unpublished paper.

Bodenhorn, Howard. 2002. "Partnership and Hold-Up in Early America." NBER Working Paper No. 8814.

Cai, Hongbin. 2003. “A Theory of Joint Asset Ownership.” Rand Journal of Economics, 34 (Spring): 63-77.

Carney, William J. 1980. “Fundamental Corporate Changes, Minority Shareholders, and Business Purposes.” American Bar Foundation Research Journal, 1980 (Winter): 69122. 
Dunlavy, Colleen A. 2004. "From Citizens to Plutocrats: Nineteenth-Century Shareholder Voting Rights and Theories of the Corporation." In Constructing Corporate America: History, Politics, Culture, ed. Kenneth Lipartito and David B. Sicilia. New York: Oxford University Press. Pp. 66-93.

Evans, George Heberton Evans, Jr. 1948. Business Incorporations in the United States, 18001943. New York: National Bureau of Economic Research.

Franks, Julian, Colin Mayer, and Stefano Rossi. 2003. "Spending Less Time with the Family: The Decline of Family Ownership in the UK." Unpublished paper.

Freund, Ernst. 1896. “The Legal Nature of Corporation.” Ph.D. dissertation, Columbia University.

Gilmore, Eugene Allen. 1911. Handbook on the Law of Partnerships Including Limited Partnerships. St. Paul, Minn.: West Publishing.

Gilson, Ronald J., and Robert H. Mnookin. 1985. "Sharing among Human Capitalists: An Economic Inquiry into the Corporate Law Firm and How Partners Split Profits.” Stanford Law Review, 37 (January): 313-92.

Grossman, Sanford J., and Oliver D. Hart. 1986. "The Costs and Benefits of Ownership, a Theory of Vertical and Lateral Integration.” Journal of Political Economy, 94 (August): 691-719.

Harris, Ron. 2000. Industrializing English Law: Entrepreneurship and Business Organization, 1720-1844. Cambridge: Cambridge University Press.

Hart, Oliver. 1995. Firms, Contracts, and Financial Structure. New York: Oxford University Press. 
Hillman, Robert W. 1982. “The Dissatisfied Participant in the Solvent Business Venture: A Consideration of the Relative Permanence of Partnerships and Close Corporations." Minnesota Law Review, 67 (October): 1-88.

Josephson, Matthew. 1934. The Robber Barons: The Great American Capitalists, 1861-1901. New York: Harcourt, Brace \& World.

Kirkland, Edward Chase. 1961. Industry Comes of Age: Business, Labor and Public Policy 1860-1897. New York: Holt, Rinehart and Winston.

Lamoreaux, Naomi R. 2004. "Partnerships, Corporations, and the Limits on Contractual Freedom in U.S. History: An Essay in Economics, Law, and Culture." In Constructing Corporate America: History, Politics, and Culture, ed. Kenneth Lipartito and David B. Sicilia. New York: Oxford University Press. Pp. 29-65. , and Jean-Laurent Rosenthal. 2004. "Legal Regime and Contractual Flexibility: A Comparison of Business's Organizational Choices in France and the United States during the Era of Industrialization." American Law and Economics Review, forthcoming.

Mark, Gregory A. 2003. “A Tentative History of the Law Governing Managerial Discretion: The Concern with Conflicts of Interest." Unpublished paper.

Marsh, Harold, Jr. 1966. “Are Directors Trustees?” Conflict of Interest and Corporate Morality." Business Lawyer, 22 (November): 35-76.

McCraw, Thomas K. 1984. Prophets of Regulation: Charles Francis Adams, Louis D. Brandeis, James M. Landis, and Alfred E. Kahn. Cambridge: Harvard University Press.

O’Neal, F. Hodge. 1978. “Close Corporations: Existing Legislation and Recommended Reform.” The Business Lawyer, 33 (January): 873-88. 
O’Sullivan, Mary. 2004. "What Drove the U.S. Stock Market in the Last Century?" Unpublished paper.

Rebitzer, James B., and Lowell J. Taylor. 2004. "When Knowledge is an Asset: Explaining the Organizational Structure of Large Law Firms.” Unpublished paper.

Richards, H. S. 1921. “Uniform Partnership Act: Conclusion.” Wisconsin Law Review, 1 (April): 147-65.

Story, Joseph. 1859. Commentaries on the Law of Partnership, as a Branch of Commercial and Maritime Jurisprudence with Occasional Illustrations from the Civil and Foreign Law. $5^{\text {th }}$ edn.; Boston: Little, Brown.

Summers, Mark Wahlgren. 1993. The Era of Good Stealings. New York: Oxford University Press.

U.S. Census Office. 1902. Twelfth Census: Manufacturers, Part I. Washington, DC: U.S. Census Office. Vol. 7.

U.S. Internal Revenue Service. Various years. Statistics of Income. Washington, DC: Government Printing Office.

Warren, Edward H. 1929. Corporate Advantages without Incorporation. New York: Baker, Voorhis \& Co.

\section{Appendix: The Case of Endogenous Equity Stakes}

The assumption that investment and equity stakes are identical seems reasonable in light of what we know about business practices in the nineteenth-century U.S. It is also justifiable on theoretical grounds. If two members of a firm are similar in all respects except for the relative 
size of their investments, Nash bargaining would lead them to split the equity according to their contributions. The assumption of equal investment and equity stakes does, however, have two important implications. The first is that the investor earns above market returns in nearly all of the firms that form. Hence the entrepreneur could increase her profit if she could reduce the investor's equity stake until his return approached that of the market. Second, some firms that do not form could have done so if the entrepreneur had been able to offer the investor a higher equity stake in order to raise his return. In this appendix, we explore the consequences of relaxing the assumption of equal equity and investment stakes so that the entrepreneur can make a take it or leave it offer to the investor. ${ }^{23}$ We assume throughout that $\mathrm{K}_{\mathrm{E}}>\mathrm{K}_{\mathrm{I}}$. Henceforth, $\mathrm{E}_{\mathrm{E}}$ will be the equity stake of the entrepreneur, and $\mathrm{E}_{\mathrm{I}}$ the equity stake of the investor.

In a partnership, the investor and the entrepreneur earn the same return on equity. Setting the investor's equity stake so that his participation constraint binds exactly implies that the investor's equity stake should be $E_{P I}=E_{I}(1+r) / R_{P I}$, where $R_{P I}=(p(1-d)+((1-p)+d p) \alpha) \Pi$. Given $K_{I}$, allowing the entrepreneur to adjust equity stakes endogenously will mean that the investor's stake will decline as $\Pi$ increases, all other things being equal. Allowing such adjustments, however, has no effect on entry decisions for partnerships. Indeed, if $d<d^{*}(\Pi), R_{\mathrm{PI}}<1+\mathrm{r}$. But because $\mathrm{R}_{\mathrm{PE}}=\mathrm{R}_{\mathrm{PI}}, \mathrm{R}_{\mathrm{PE}}<1+\mathrm{r}$, and the entrepreneur will not want to enter. Hence investors in a partnership never have an equity stake that is larger than their investment stake.

In corporations, returns per unit of equity are not same for the investor and for the entrepreneur because the latter enjoys the benefits of control. Setting the investor's equity stake so that his participation constraint binds exactly implies that $\mathrm{E}_{\mathrm{Cl}}=\mathrm{E}_{\mathrm{I}}(1+\mathrm{r}) / \mathrm{R}_{\mathrm{CI}}$, where $\mathrm{R}_{\mathrm{Cl}}=(\mathrm{p}+(1$ -

\footnotetext{
${ }^{23}$ This change allows us to examine more complicated bargains than simple Nash bargaining. Nevertheless, we do not go so far as to allow side contracts to eliminate problems of minority oppression in corporations. The empirical record (particularly the persistence of large numbers of partnerships in all sectors of the economy and the extent of the litigation over minority oppression) simply will not support such a modification.
} 
p) $\alpha)(1-\omega) \Pi$, or $E_{C l}=E_{I}(1+r) / R_{C}(1-\omega)$. As in the case of partnerships, when $\Pi>\Pi^{*}$, investors earn above market returns, so allowing entrepreneurs to set equity stakes would lead to declining shares for investors as $\Pi$ increases. Unlike the case of partnerships, however, entrepreneurs can affect entry decisions by varying equity stakes. Because the entrepreneur enjoys the benefits of control, some firms do not form because the investor's return would be less than the market's even though the firm's return would have been greater than the market's. In these cases, the entrepreneur can transfer some of her return to the investor by increasing his equity stake just enough to encourage participation. There is, however, an important constraint on this strategy: the entrepreneur must not loose control. This constraint implies that, holding $\mathrm{r}, \mathrm{p}, \alpha, \omega$, and $\mathrm{K}_{\mathrm{I}}$, and $K_{P}$ fixed, there will be a unique $\Pi^{*}{ }^{*}$ below which corporations will not form. Because $\Pi^{*}{ }^{\mathrm{m}}<\Pi^{*}$, allowing the entrepreneur to set equity stakes will increase the range of profits over which corporations form.

The entrepreneur wants to transfer just enough equity to the investor to make him indifferent between participating in the firm and investing in the market. If the investor's equity stake becomes larger than a half, he gains not just additional income rights but also the private benefits that come with control. This non-linearity makes the entrepreneur's problem difficult when $K_{I}$ is close to one half of $K$. If the profitability of the firm (П) is too low, the entrepreneur may find it difficult to satisfy the investor's participation constraint if she forms a corporation. That is, as the firm's return rises, the equity stake that has to be given to the investor in exchange for a given contribution declines. Conversely, as $\omega$ increases, because the entrepreneur's private benefits of control increase, the investor must get a larger share of the equity for a given contribution in order to satisfy his participation constraint. This larger share in turn makes it more difficult for the entrepreneur to insure that she retains control. Hence the comparative 
advantage of the partnership form increases when the two members of the firm have relatively even investment stakes. When the cost of untimely dissolution is low, the entrepreneur will form a partnership instead. 
Figure 1: How Profit Rates and the Probability of Withdrawal Affect

Whether or Not Partnerships Will Form

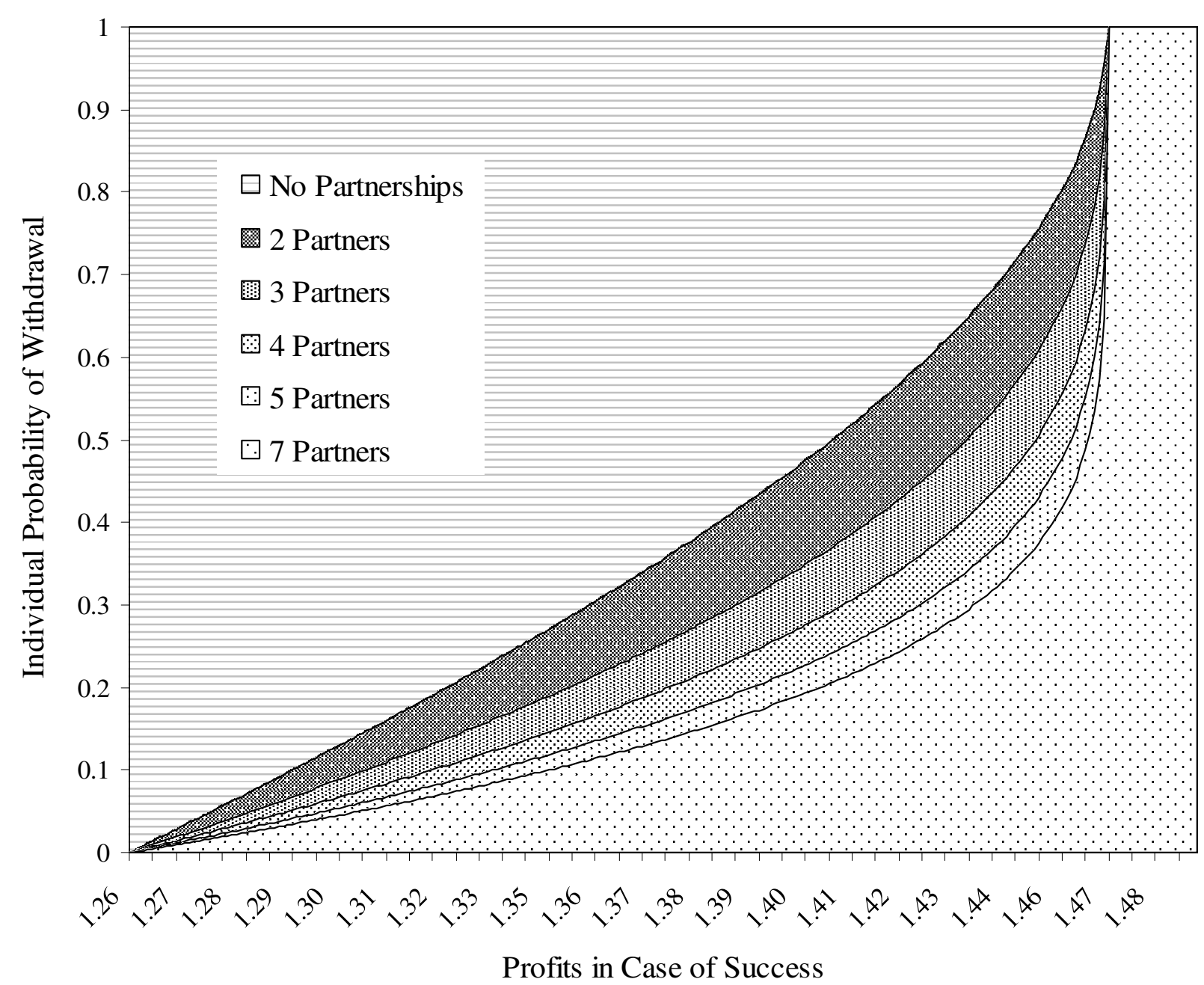

Note: The probability of dissolution is $\left(1-(1-\mathrm{d})^{\mathrm{n}}\right.$, where $\mathrm{d}$ is the individual probability of withdrawal and $\mathrm{n}$ is the number of partners. 
Figure 2: The Choice of Organizational Form as a Function of the Probability of Dissolution, Holding Private Benefits of Control Constant

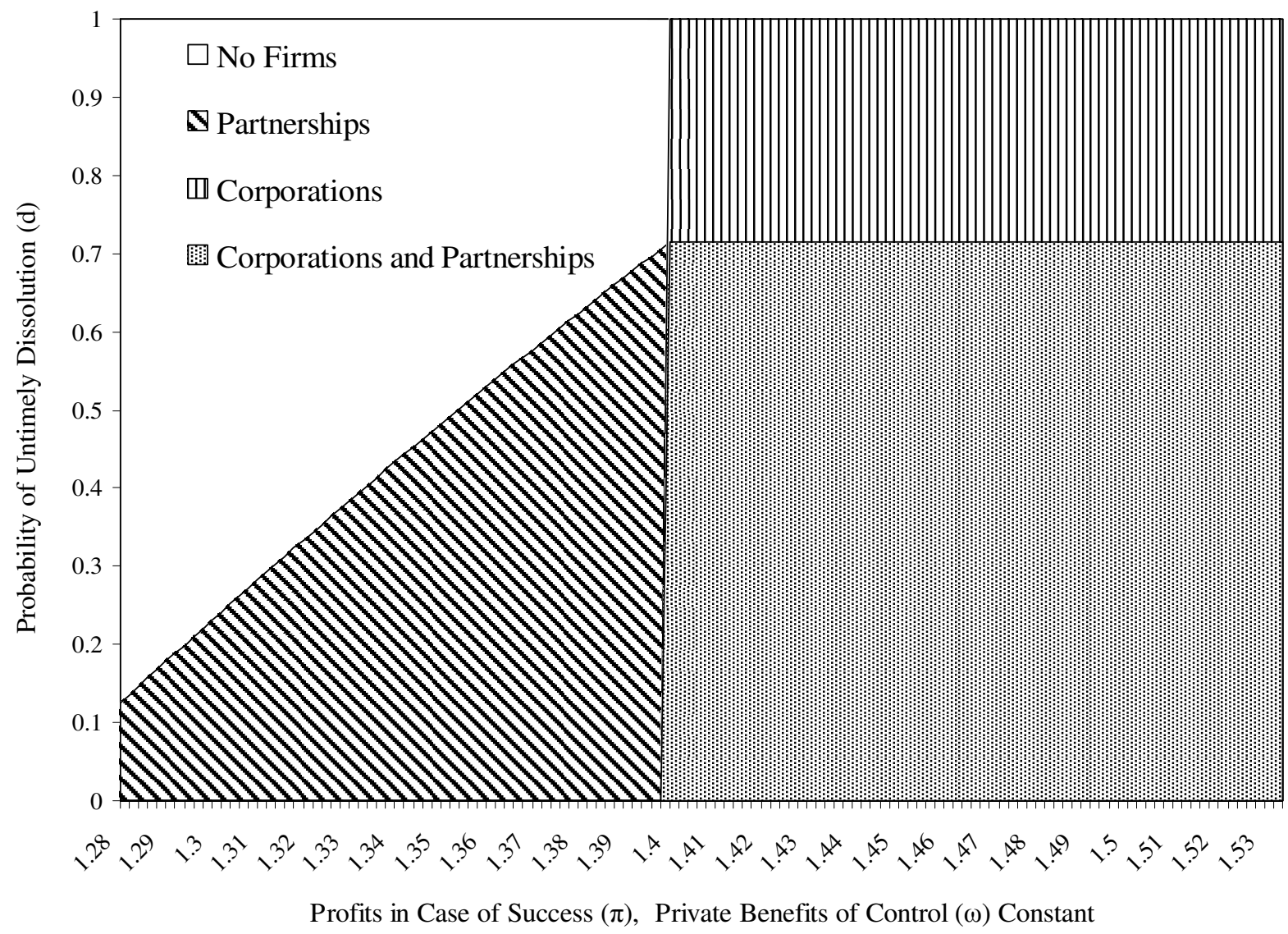

Note: $\mathrm{d}^{*}(\Pi)$ is the line that separates the "no firms" area from the "partnership" area. $\Pi^{*}=1.4$. 
Figure 3: The Choice of Organizational Form as a Function of the Extent of Private Benefits of Control, Holding the Probability of Dissolution Constant

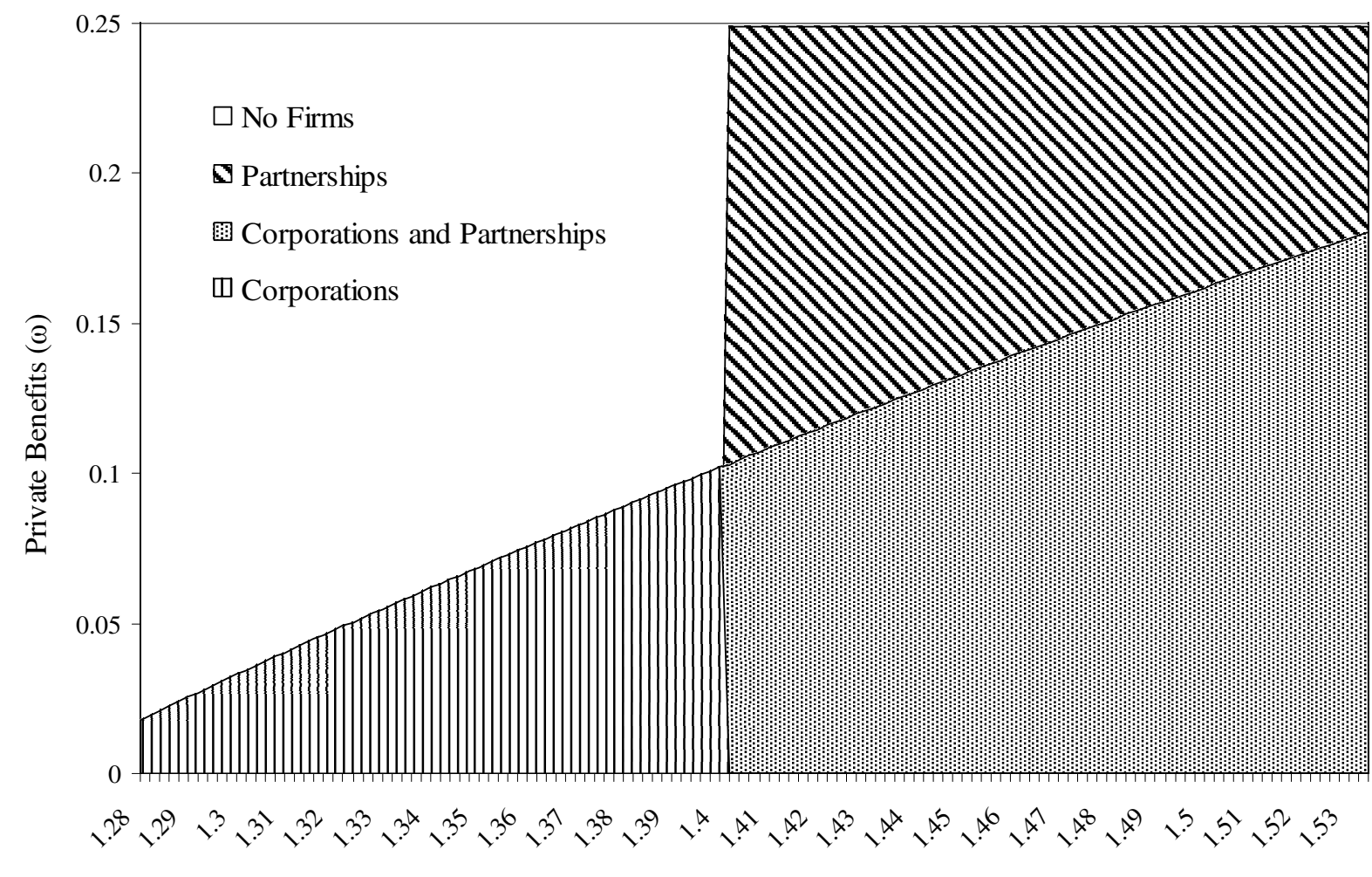

Profits in Case of Success $(\pi)$, Probability of Untimely Dissolution (d) Constant

Note: $\omega^{*}(\Pi)$ is the line that separates the "no firms" area from the "corporations" area. $\Pi^{*}=1.4$. 